\title{
موقف الفقهاء المسلمين من منطق أرسطو
}

\section{د. دإسماعيل سالم فرحات}

جامعة مصراتة - كلية الآداب

\section{تمهيد:}

على الرغم من اهتمام المسلمين بالمنطق الأرسطي، وبلائهم فيه بلاء حسن منذ البداية، إلا أن موقف علماء وفلاسفة الإسلام من المنطق الأرسطي لم يكن موقفًا موحدًا، بل لقد مند انقسموا في موقفهم حول الوافد الغريب "المنطق" إلى موقفين: الأول: وهو موقف القبول هذا العلم والدفاع عنه، والذي بدا واضحا في مولين موقف الغزالي وابن حزم وغيرهما.

الثاني: وهو موقف الرفض لهذا العلم ويمثله بعض الفقهاء والمتكلمين، فقد وقفوا منه موقفًا عدائيّا وتنوعت حملاتمم القاسية عليه. صحيح أن الإمام الغزالي بذل جهادًا كبيرًا في سبيل ربط المنطق بالفقه بغض النظر إلى قيمته الموضوعية، وبغض النظر عن مدى تناسق دعوته هذه مع موقفه العام من الفلسفة

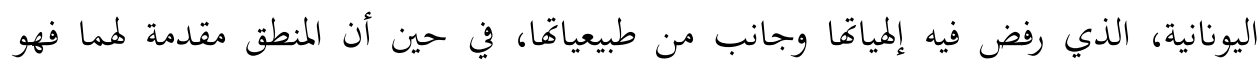

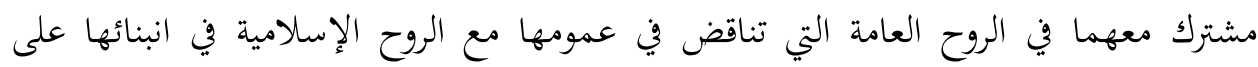
الإلحاد، بغض النظر عن ذلك كله فقد نجح في إدخال المنطق إلى حظيرة العلوم الإسلامية مما

جعل تاريخ هذا العلم في الثقافة الإسلامية، ينقسم إلى عهدين: عهد الرفض، وعهد القهد القبول (1).

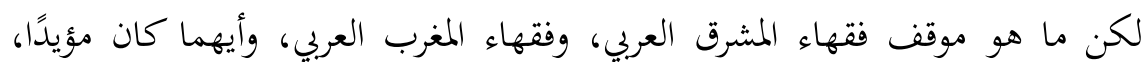
وأيهما كان معارضًا لتوجه الغزالي؟

1- جلال الدين السيوطي: صون المنطق والكلام عن فن المنطق والكلام، علق عليه: علي سامي النشار، مطبعة السعادة، القاهرة، 19 46، صلال السيوطي صون لمنطف 
هذا ما سوف نحاول تناوله في هذا البحث، وإن كنا سوف نركز على موقف ابن تيمية؛ لأنه تصدى تصديا كبيرً للمنطق في القرن السابع الهجري. أولاً: موقف فقهاء المشرق العربي من المنطق الأرسطي:

أحدثت دعوة الغزالي وموقفه من المنطق شقاقًا في مواقف الفقهاء بخصوص المنطق، ففريق بقي على موقف الرفض التام للمنطق، والذي كان أكثر حدة وأشد شوكة وأقوى تركيزًا من الرفض الذي وقفه الإمام الشافعي من قبل، وكأنما هو رد فعل جاء في قوة الفعل الذي قام به الغزالي في تحمسه لمنطق أرسطو.

وقبل أن نتحدث عن مظاهر فقر المنطق الأرسطي في المشرق العربي ومعالم هذا الفقر نود الإشارة إلى بدايات هذا الرفض، التي تبلورت على يد الإمام الشافعي، والتي تبناها بعده فقهاء المشرق العربي.

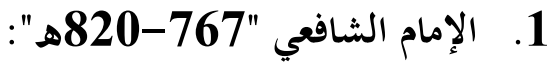

رفض الإمام الشافعي علم المنطق الأرسطي؛ لأنه فيما يرى لا يمكن أن يجري على إنى

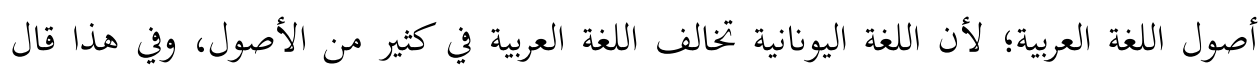

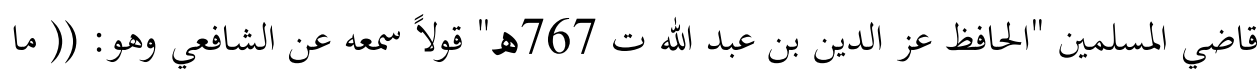
جهل الناس ولا اختلفوا إلا لتركهم لسان العرب وميلهم إلى لسان أرسطو طاليس ()) (1). ويرى السيوطي"1445-1505م" أن الغرض من كلام الشافعي أن من أراد تخريب

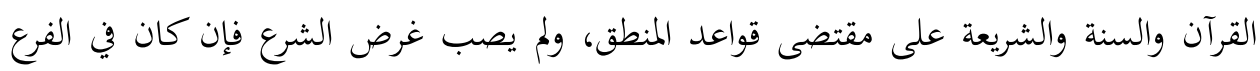

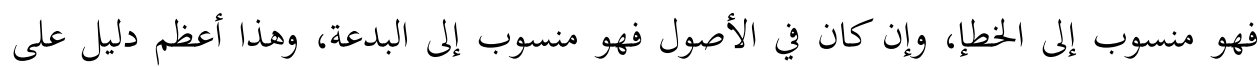
تحريم هذا الفن وهذا هو مجمل كلام الشافعي (2). وبالرغم من هذا الموقف الذي اتخذه الشافعي إلا أن هناك من المعاصرين من ذهب إلى هُ هلى أن الشافعي قد تأثر في منهجه الأصولي بالمنطق الأرسطي، منهم إبراهيم مدكور، وعلي سامي

$$
\text { 2- 1- جلال الدين السيوطي، المصدر السابق، ص15. }
$$


النشار، الذي أشار إلى مجموعة من الحجج التي يستند إليها أصحابها في قولمم لتأثر الشافعي بالمنطق الأرسطي، كما يؤكد حسن عبد الحميد على تأثر الشافعي بمنطق أرسطو، وهذا واضح بلا شك بخاصة في نظرية قياس الشبه التي أرسى قواعدها الإمام الشافعي، كما أنَّ نظرية قياس

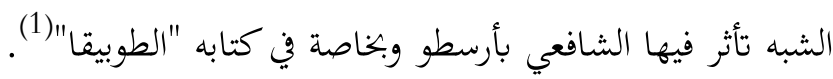
غير أن بعض المستشرقين يرون أن نظرية قياس الشبه لم تتأثر بمنطق أرسطو مباشرة، وإنما

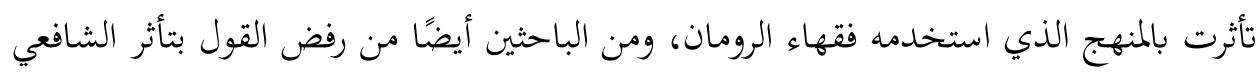

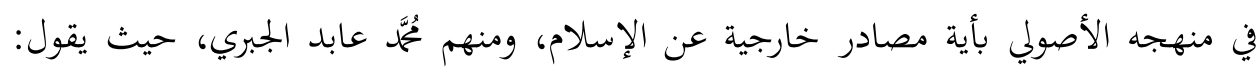

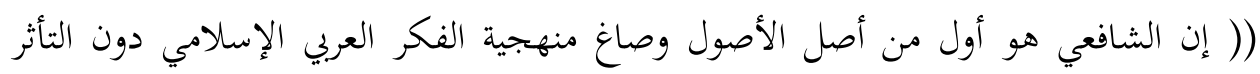
بمؤثرات يونانية () (2)

\section{2.}

ابن الصلاح يؤكد أن الفلسفة شر، والمنطق مدخل الفلسفة، إذًا مدخل الشر (")

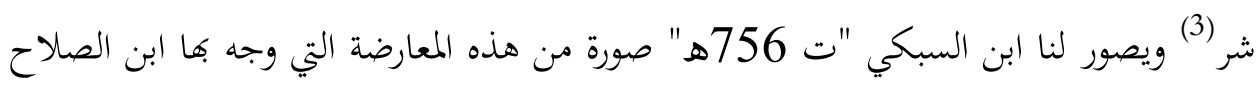
فيذكر: أن ابن الصلاح "ت 643هـ" قد ارتحل إلى الموصل كي يتعلم على يد كمال الدين ابن يونس "1156-1242م" دروسا في المنطق سرًّا، ولكن ابن الصلاح لم يستطع استيعاب هذا العلم، فقد كان ابحاهه دينيّا خالصا، فعندئذ قال له الشيخ كمال الدين: يا فقيه المصلحة

1- حسن عبد الحميد: المنهج في علم أصول الفقه، ضمن كتاب في فلسفة العلوم ومناهج البحث الذي كان

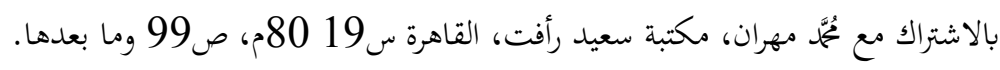

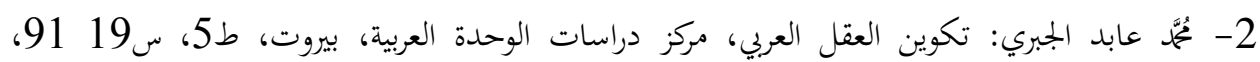
ص100.

(*) على الرغم من رفض ابن الصلاح للمنطق إلا أنه قد صاغ رفضه في قياس من الشكل الأول وهذا يشير إلى أنه كان على دراية بعلم المنطق.

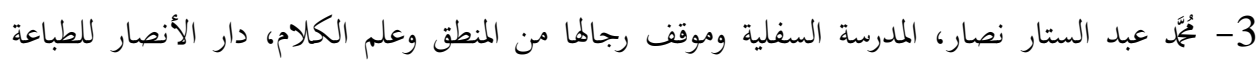
والنشر والتوزيع، 19 79، ص29 29. 
عندي أن تترك الاشتغال بهذا الفن فقال له: ولم ذلك يامولانا؟ فقال: لأن الناس يعتقدون فيك

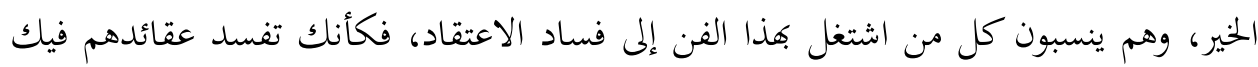
وما يكصل لك من هذا الفن، واستجاب ابن الصلاح لنصيحته وترك الاشتغال بالمنطق، ولم

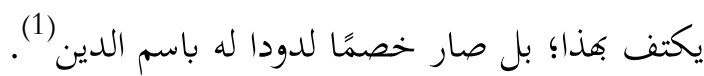
ومن الملاحظ هنا أن ابن الصلاح في بداية أمره فعل كما فعل البعض الذين أرادوا أن يتعلموا علم المنطق سرًا خوفًا من الاتحام بالكفر والتعرض للأذى، ولولا نصيحة الشيخ كمال الدين بن يونس له بترك الاشتغال بهذا العلم، لكان من الممكن أن يستمر في دراسته خفية.

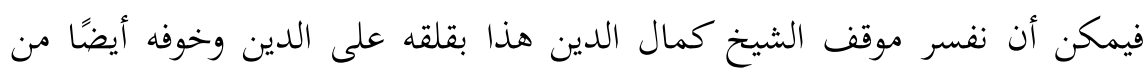
حكم الناس على ابن الصلاح بفساد عقائدهم بسبب تعلمه علم المنطق بعد أن كانوا يثقون فيه

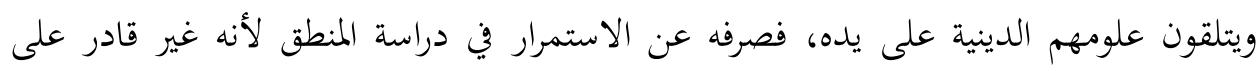
ذلك، فلكي يشجعه على ترك هذه الدراسة ذكره بأن من يعمل فيها يتهم في دينه، ولما كان هو

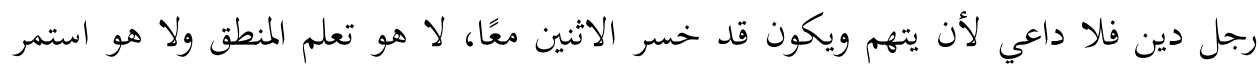
يحوز ثقة الناس في الدراسات الدينية. وهكذا بدأ ابن الصلاح عداءه للمنطق، وعلل سبب الاشتغال به أنه عندما احتك

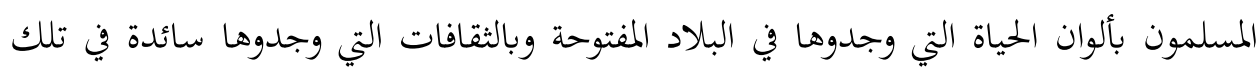

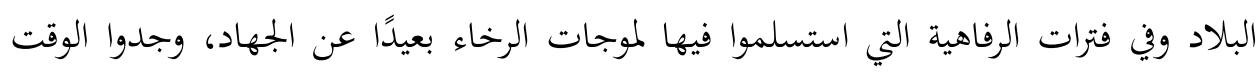
للتفكير والرأي والمذهبية واشتغلوا بالفلسفة الإغريقية التي ترجمت إلى اللغة العربية، ولقد استطاعوا

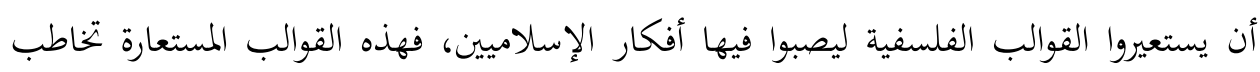

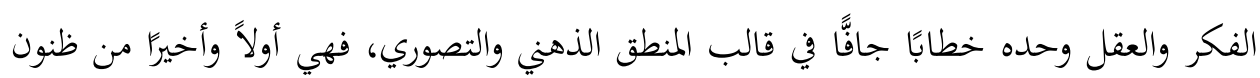
البشر (2)

1- ابن السبكي، طبقات الشافعية، المطبعة الحسينية، ط1 القاهرة، د ن ت، ص160. 160

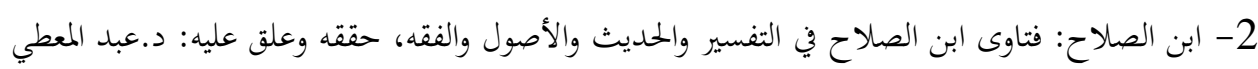

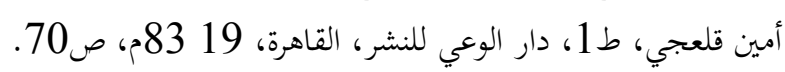


فمن أجل هذا كانت فتوى ابن الصلاح ضد المنطق، فقد وجه إليه العديد من التساؤلات في حق من يشتغل بالمنطق والفلسفة تعليمًا وتعلمًا.

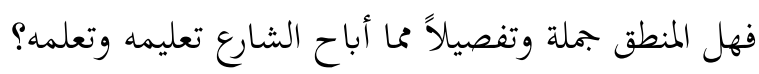
وهل ذكر التابعون والأئمة المجتهدون والسلف الصالح ذلك أو أباحوا الاشتغال به؟

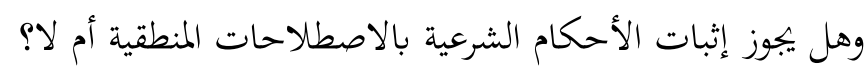
أجاب ابن الصلاح على هذا: (( بأن المنطق هو مدخل الفلسفة، ومدخل الشر شر، إنسات وليس الاشتغال بتعليمه وتعلمه مما أباح الشارع ولا استباحه أحد من الصحابة والتابعين والأئمة المجتهدين والسلف الصالحين وسائر من يقتدي بهم من أعلام الأئمة وسادتما وأركان الأمة وقادتا، وأما استعمال الاصطلاحات المنطقية في مباحث الأحكام الشرعية فمن المنكرات المستبشعة والرقاعات المستحدثة وليس بالأحكام الشرعية، والحمد لله فالافتقار إلى المنطق أصلاً وما يزعمه المنطق للمنطق من أمر الحد والبرهان فقاقيع قد أغنى الله عنها كل صحيح الذهن لاسيما من خدم نظريات العلوم الشرعية، ولقد تمت الشرعية وعلومها وخاض في بحار الحقائق والدقائق علمائها، حيث لا منطق ولا فلسفة ولا فلاسفة، ومن زعم أنه يشتغل مع نفسه بالمنطق

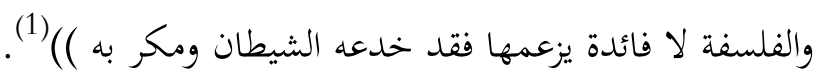
وهكذا اعتبرت فتوى ابن الصلاح لمن جاء بعده من الفقهاء الذين يهاجمون المنطق الحجة التي يستند إليها في تحريم هذا العلم، فكانت ذات أثر بالغ في التيار المعارض للمنطق

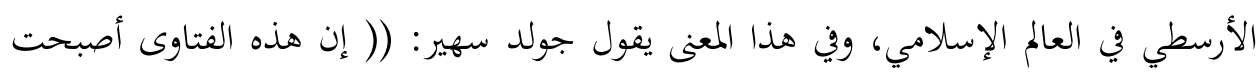

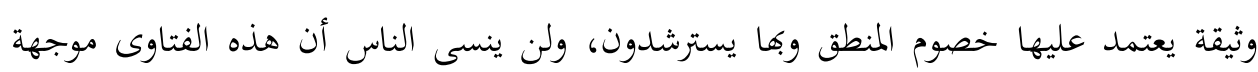
ضد الغزالي؛ لأنه هو الذي أدخل مناهج المنطق في الفقيهات ()) (2).

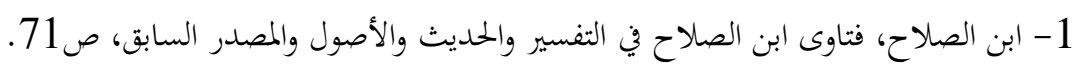

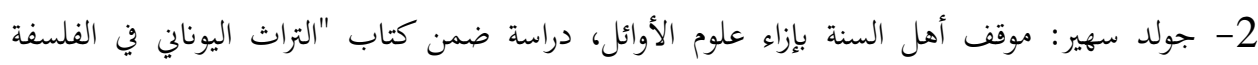

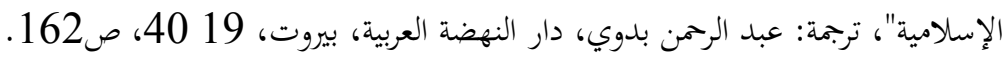


كما كان لفتاوى ابن الصلاح الأثر البالغ في العالم الإسلامي حيث أخذ بها كل من خاصموا المنطق والفلسفة بعد ذلك، ومن هؤلاء "طاث كبرى زاده ت 962هـ" الذي يقول: (( وإياك أن تظن من كلامنا هذا أو تعتقد أن كل ما أطلق عليه اسم العلم؛ حتى الحكمة المموهة التي اخترعها الفارابي وابن سينا ونفحها نصير الدين الطوسي ممدوحًا، هيهات هيهات

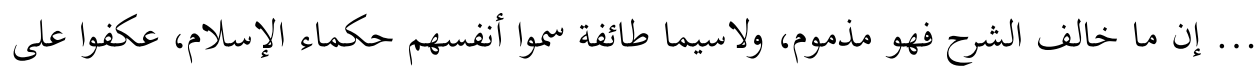
دراسة ترهات أهل الضلال وسموها الحكمة وربما استهجنوا من عدا عنها وهم أعداء الله وأعداء

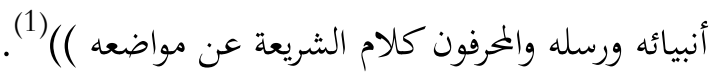

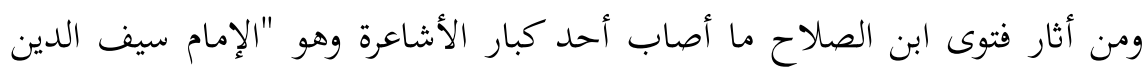
الآمدي631-531-6ه" من جراء اتمامه بالفلسفة والمنطق، فقد كان واسع الاطلاع في العلوم الدينية والعلوم القديمة على السواء؛ وقد نزل في القاهرة وتولى تدريس العلوم الشرعية فيها، ولكن شهرته بالاشتغال بالفلسفة والمنطق قد آذته كثيرً بالرغم من أنه كان لا يدخل شئيًا من العلوم

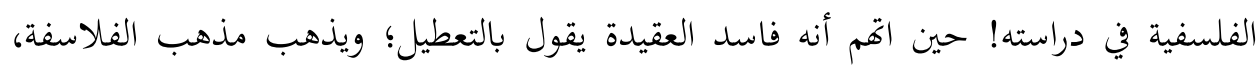
وقد كُتب بهذا مضر وقع عليه الكثيرون وأعلنوا استباحة دمه، ولكنه فر إلى الشام وقام

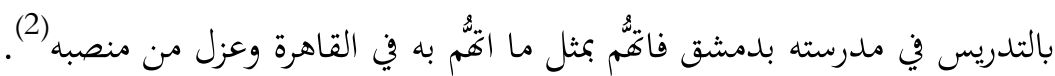
وانطلاقًا من فتوى ابن الصلاح أكد جلال الدين السيوطي أن الاشتغال بتعليم المنطق

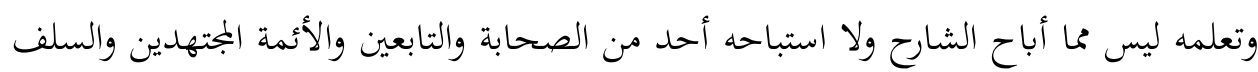

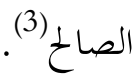
وإذا دققنا النظر إلى الدوافع التي أدت بالسيوطي إلى كراهية المنطق وجدنا أها نفس العقيدة القديمة التي كانت وراء فتوى ابن الصلاح السابقة، فقد حاول السيوطي أن يدرس الني إنس

1- طاش كبرى زاده: مفتاح السعادة ومصباح السيادة، ط1، م3، دار الكتاب العلمي، بيروت، د ن ت، ص 21 2- جولد سهير: موقف أهل السنة القدماء بإزاء علوم الأوائل، ص162.

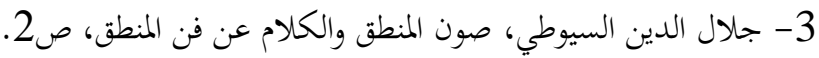


المنطق كما حاول ابن الصلاح من قبل؛ ولكن انتهت محاولته بالفشل هو الآخر وفي هذا يقول

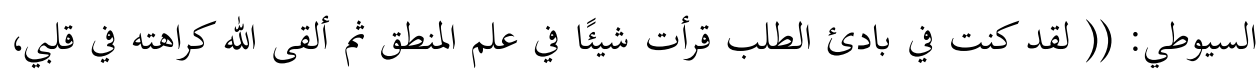
وسمعت أن ابن الصلاح أفتى بتحريمه فتركه كذلك )( ) (1).

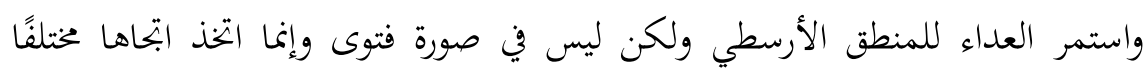

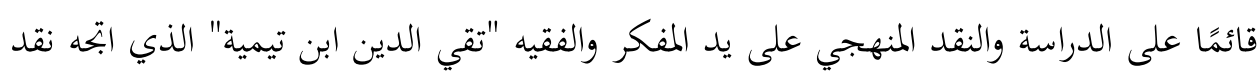
المنطق عنده إلى النقد الداخلي، أي: تناول المنطق ذاته وتحليل مسائله.

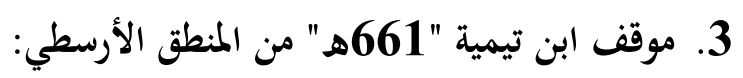

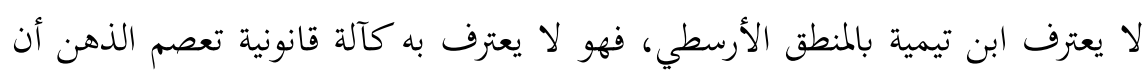

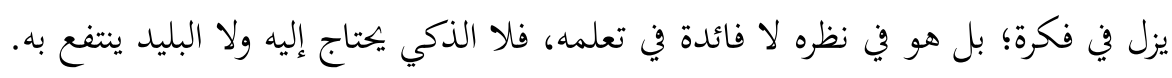

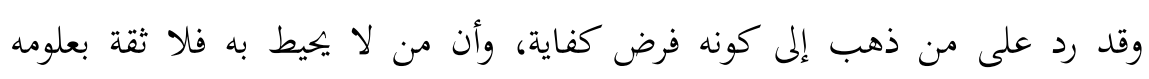

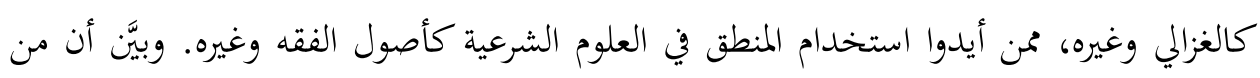

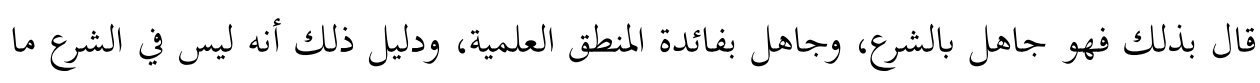

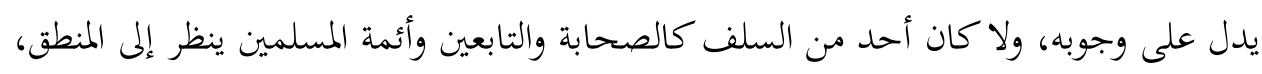

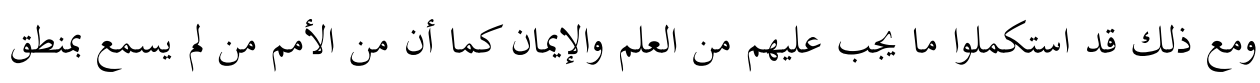

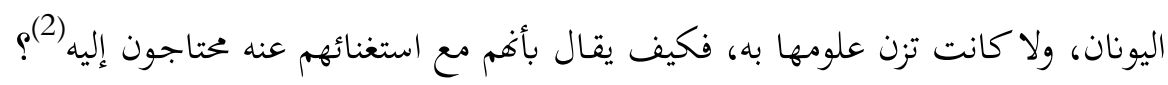

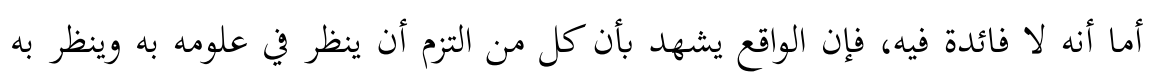
إلا وهو فاسد النظر والمناظرة، كثير العجز من تحقيق علم وبيانه (3).

1- د.يُجة عبد الستار نصار، المدرسة السفلية وموقف رجالما من المنطق وعلم الكلام، دار الأنصار للطباعة

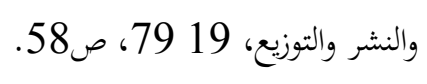

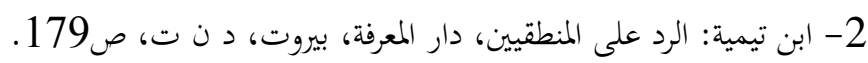

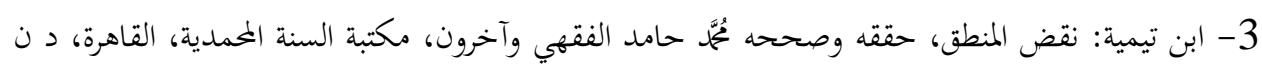


فأهل المنطق الخائضين في العلوم أقل الناس علمًا وتحقيقًا وأكثرهم شًَّا واضطرابا، ولم

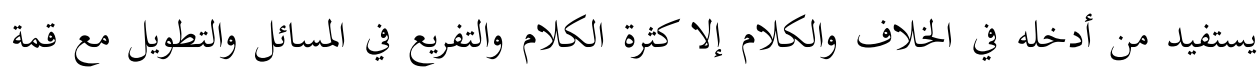

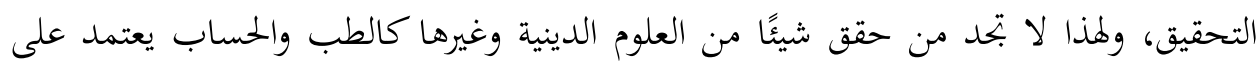

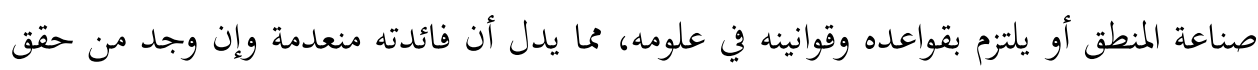
شئًا من العلم من أهل المنطق فذلك راجع إلى صحة المادة التي ينظر فيها، وصحة ذهنه وإدراكه

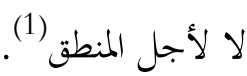
فهذا مما يبين عدم صلاحية المنطق "في نظر ابن تيمية" ليكون ميزانًا للحق، وقد انتقد أبا حامد الغزالي لكونه أدخل المنطق في علوم المسلمين ودعا إلى استخدامه وحث عليه في بعض لئه لئه مصنفاته.

يقول ابن تيمية في هذا الصدد: (( فأما أبو حامد فقد وضع مقدمة منطقية في أول المستصفى، وزعم أن من لم يهط بها علمًا فلا ثقة له بشيء من علومه، وصنف في ذلك محك

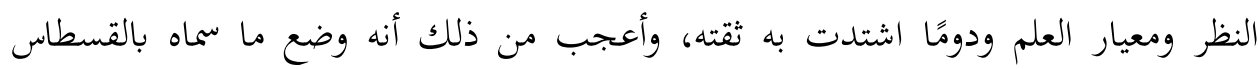

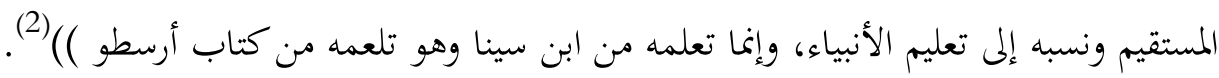

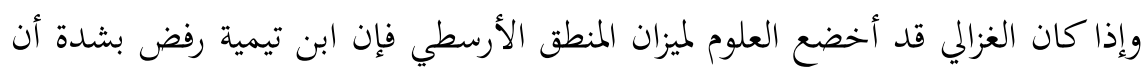

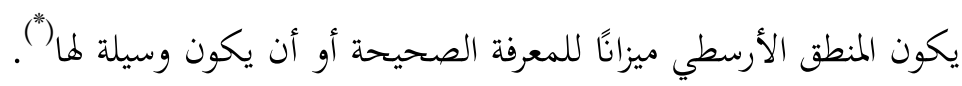
وقد حاول أن ينقض القواعد التي يقوم عليها المنطق ويشكك في مسلماته التي تلقاها المناطقة بالقبول، مثل قولهم: إن التصور لا ينال إلا بالحد، وإن التصديق لا ينال إلا بالقياس، ولم يكتف بالإشارات العامة في نقده لأسس المنطق، وإنما فصل القول في الكشف عن الجوانب

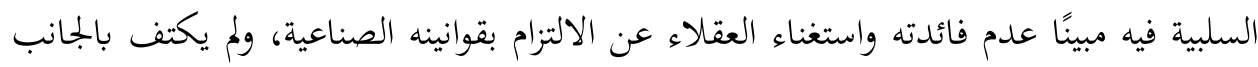

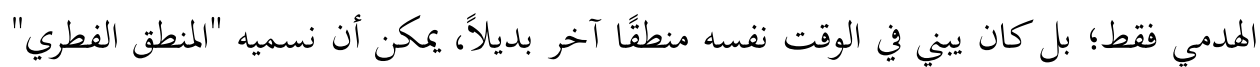

$$
\text { 2- 1- ابن تيمية، نقض المنطق، ص168. }
$$

(*) وهنا فإن ابن تيمية أشار إلى ما قاله الغزالي في كتابه القسطاس المستقيم. 
الذي يقوم على لزوم الدليل للمدلول، وعلى قياس التمثيل والتعليل. ولا يهمني الوقوف على

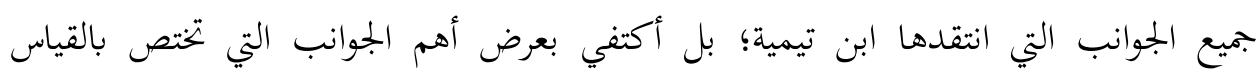

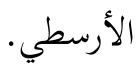

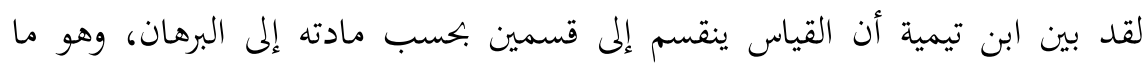

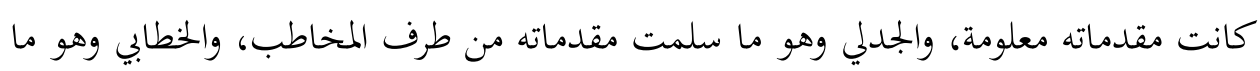

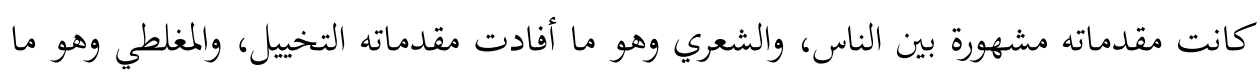
كانت مقدماته سفسطائية مموهة (1). وأما بحسب صورته فينقسم إلى القياس الاقتراني أو الحملي والقياس الاستنائي وهو

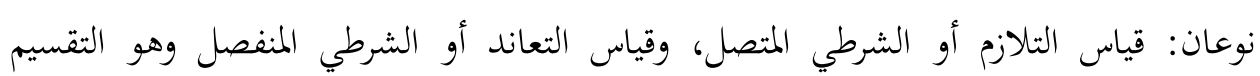
والترديد (2).

ومن جملة الأمور التي انتقدها ابن تيمية على أهل المنطق:

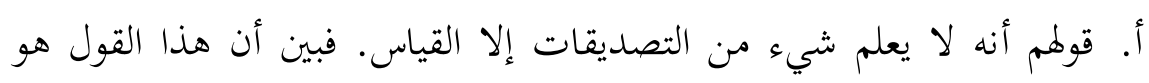

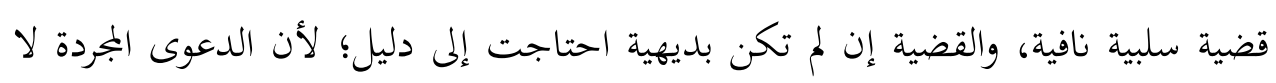

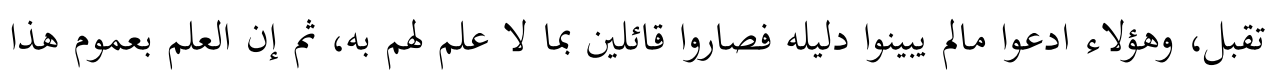

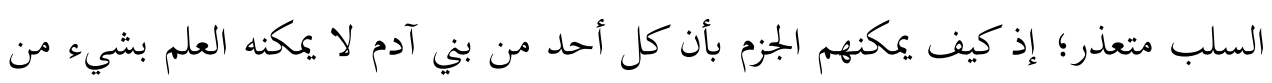

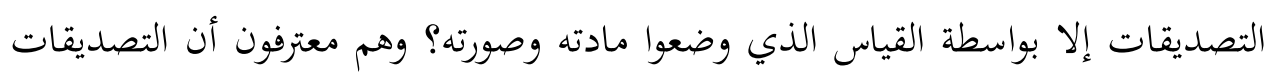

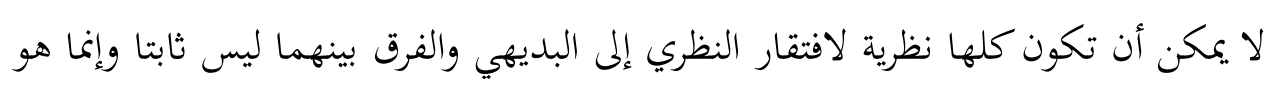
نسبي وإضافي (3)

$$
\begin{aligned}
& \text { 1- ابن تيمية، نقض المنطق، ص158. }
\end{aligned}
$$

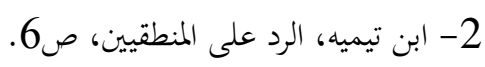

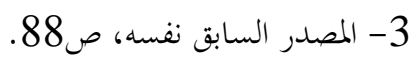


ب. قولم بأن العلوم اليقينة النظرية لا تحصل إلا بالبرهان الذي هو عندهم قياس

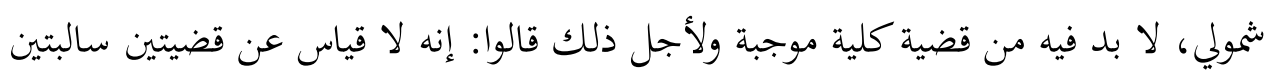
ولا عن جزئيتين (*).

والعلوم اليقينية التي هي مبادئ البرهان هي الحسيات بنوعيها الباطنة والظاهرة،

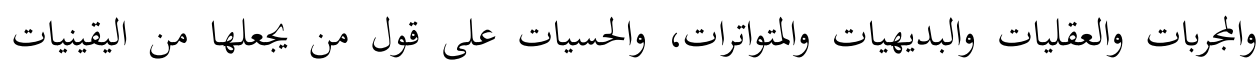

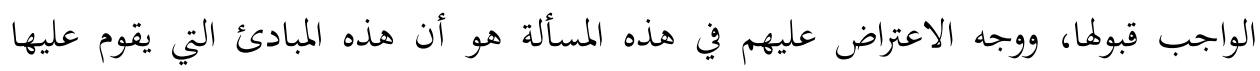

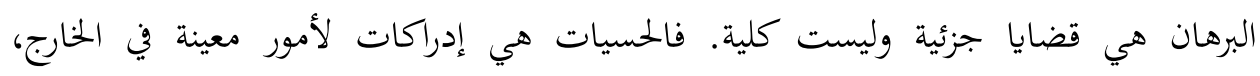

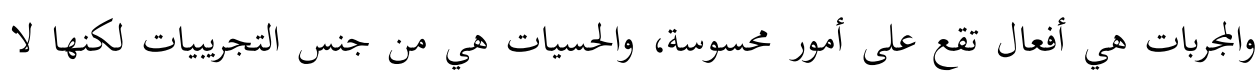

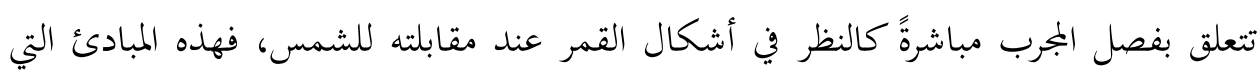

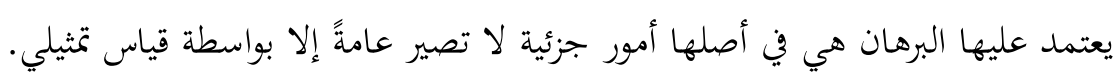

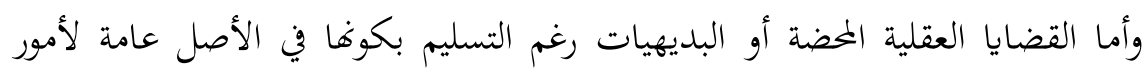

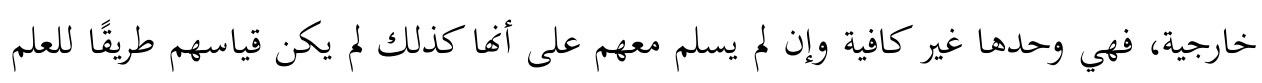

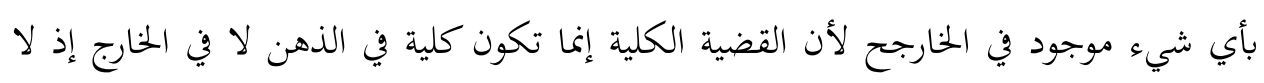
يوجد إلا ما هو معين.

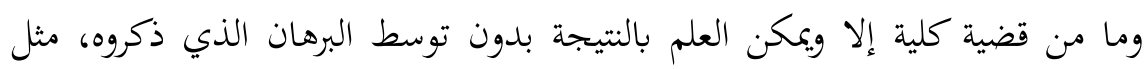

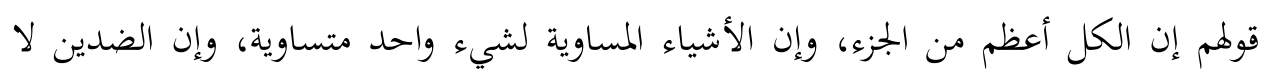

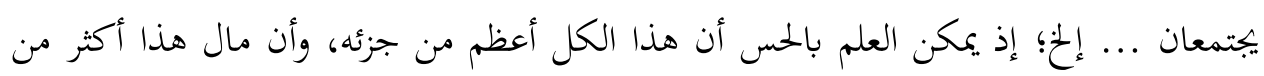

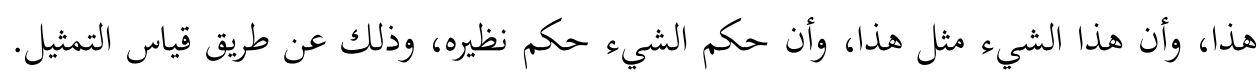

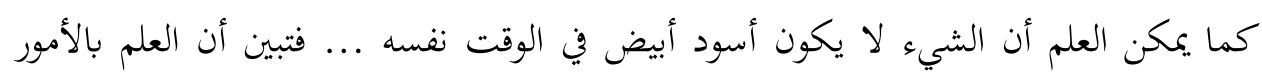

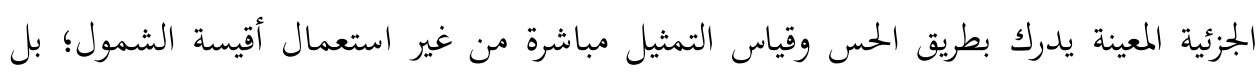
العلم بما بذلك الطريق أصح وأوضح وأكمل (1).

(") وهذا يشير إلى المساس ببعض قواعد القياس الأرسطي.

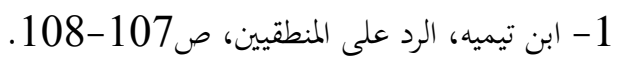


ج. قولم إن الاستدلال لابد فيه من مقدمتين بلا زيادة ولا نقصان، هو قول باطل

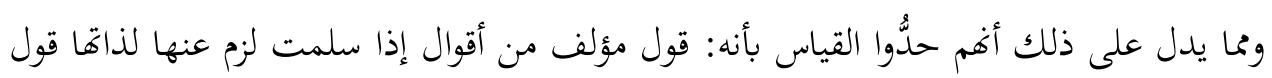

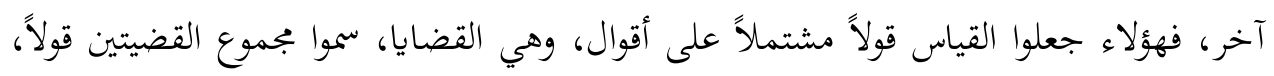

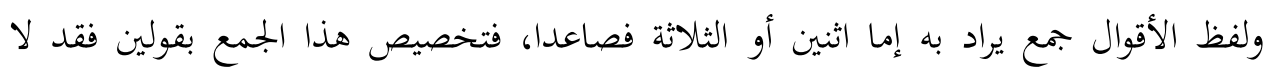

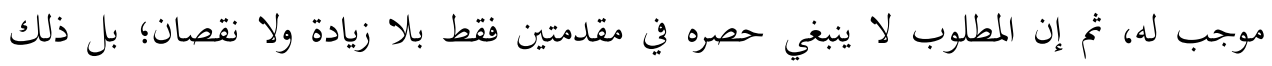

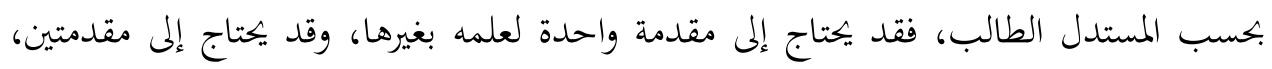

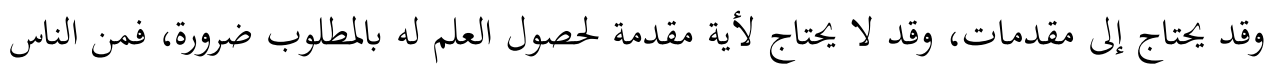

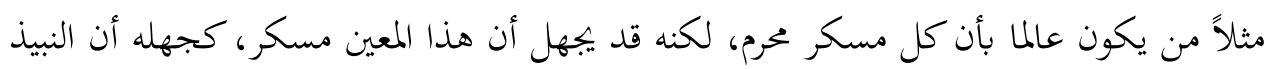

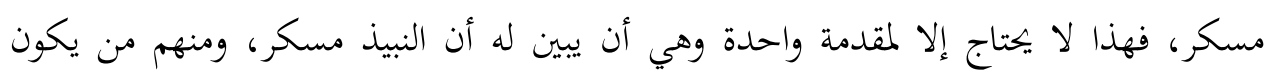

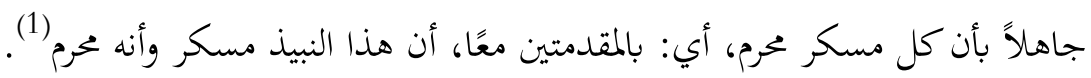

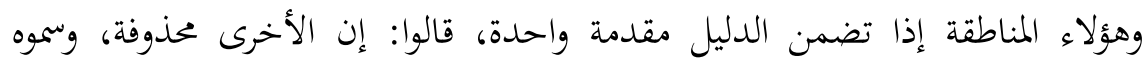

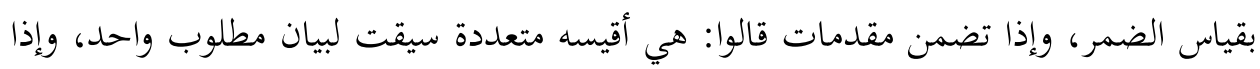

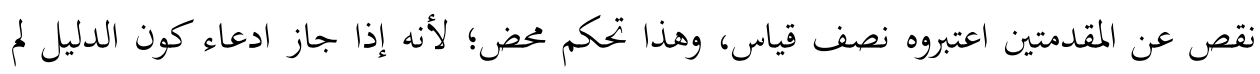

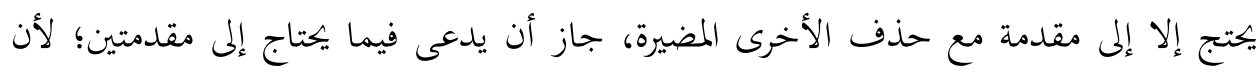

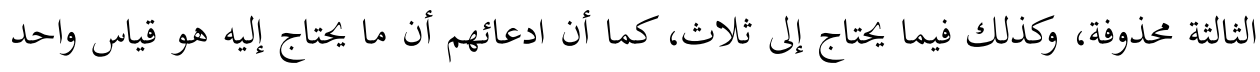

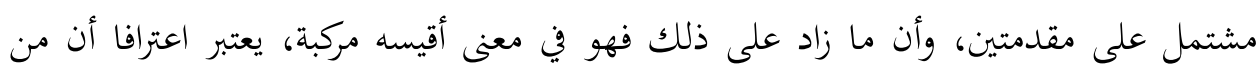

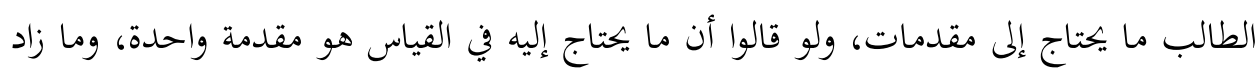

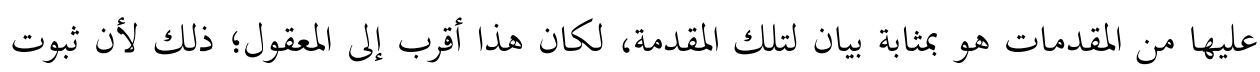

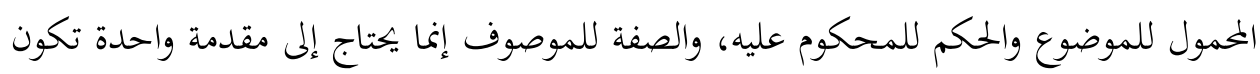

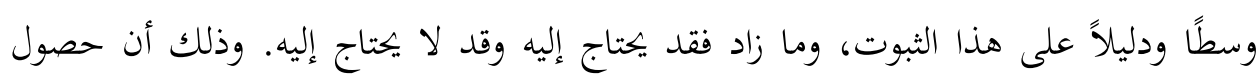

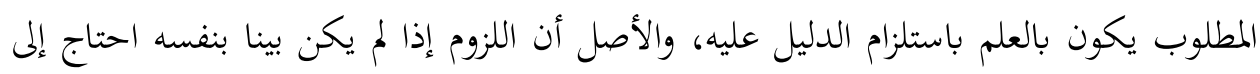

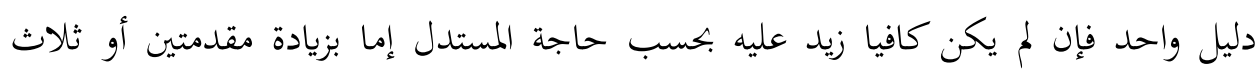

$$
\text { 1- 1 - 1بن تيميه، نتض المنطق، ص205-206. }
$$


مقدمات أو أربع.

وهذا هو الصحيح الذي عليه طوائف العقلاء غير هؤلاء المنطقيين الذين يلتزمون

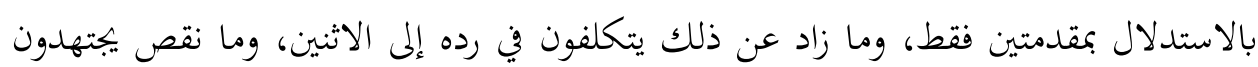
في تكميله، ولأجل هذا كان في أهل المنطق من القصور في العقل والعجز عن البيان وكثرة العي

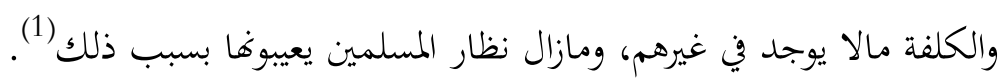

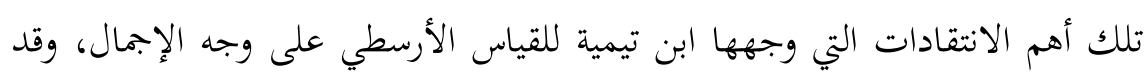
قصد بها بيان أن طرق الاستدلال ليست منحصرة في طريق القياس المنطقي، ولا هو مغن عنها؛ بل للناس من الطرق ما يحصلون به المطلوب أفضل من هذه الطريق.

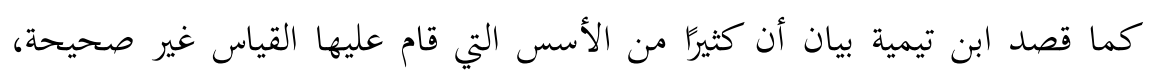

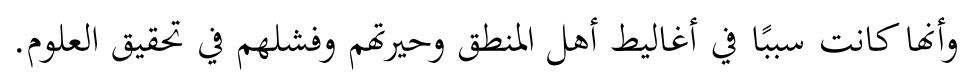

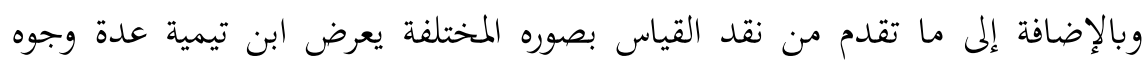
لانتقادات الحد والمنطقية الكلية، وفيما يلي بياها:

أ. قول المناطقة إن التصور الذي ليس بديهي لا ينال إلا بالحد:

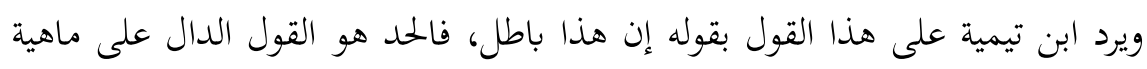

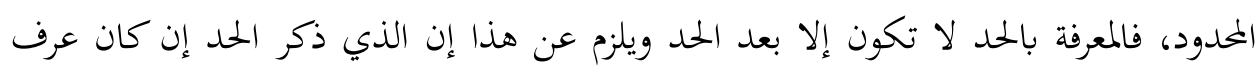

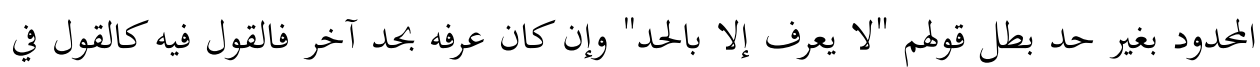
الأول (2) ونجد هنا أن اعتراض ابن تيمية هنا لا يقوم على أساس سليم خاصة قوله: (( إن الحد هو القول الدال على ماهية المحدود )).

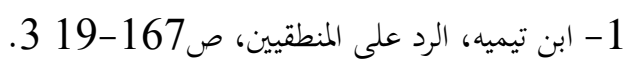
2- 2- ابن تيمية: نقض المنطق، ص184. 
فأي محدود يقصده ابن تيمية؟ وأي شيء حدده بدون حد؟ اعتقد ان ابن تيمية يهاجم

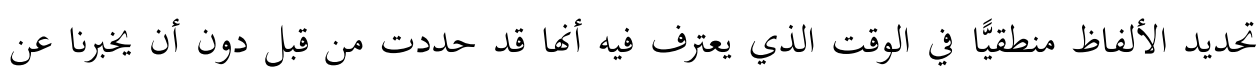
ماهية حدودها.

\section{ب. قول المناطقة "إن المعرفة متوقفة على الحمدود":}

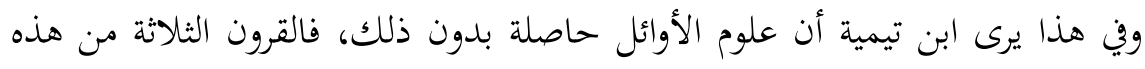

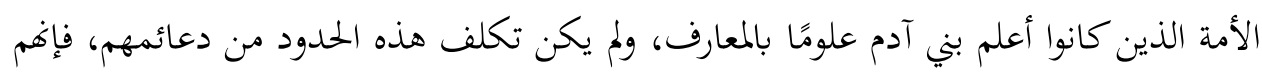
لم يبتدعوها، وكذلك فيما يقول ابن تيمية أن أئمة علوم النحاة لم يتكلف أحد منهم حد الاسم والفاعل ونخو ذلك. وإذا كان بعض فقهاء الطهارة يتكلفون هذه الحدود بينهم فإلى الساعة لم يسلم لهم أحد، وكذلك حدود أهل الكلام (1). ونسلم مع ابن تيمية في عدم استخدام الأوائل لهذه الحدود بالرغم من تقدمهم، وبخاصة في الطب والحساب، وهكذا فإن علوم الأوائل لم تكن على درجة عالية من التعقيد اللفظي الذي يحتاج إلى تحديد المعاني والألفاظ حتى لا تقع في الخطإ نظرًا لاختلاطها، كما أن علم الحساب كمثال يذكره

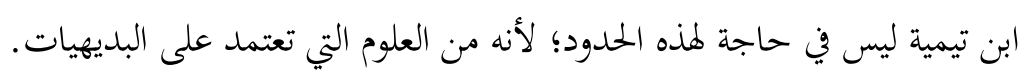
ج. قول المناطقة: "بأن الحدود هي التي تفيد تصور الحقائق":

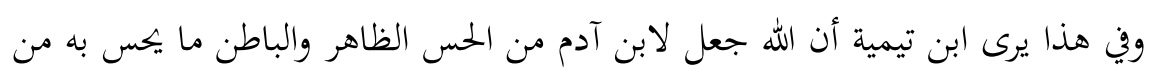

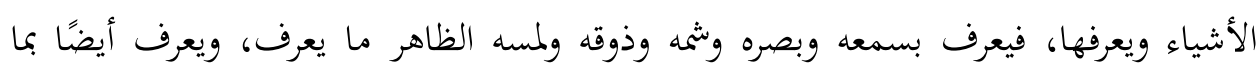
يشهاه ويحسه بنفسه وقلبه ما هو أعظم من ذلك، وهذه هي الطرق التي تعرف بها الأشياء. فأما الكلام فلا يتصور أن يعرف بمجرد مفردات الأشياء إلا بقياس تمثيلي أو تركيب ألفاظ، وليس وفيس شيء من ذلك يفيد تصور الحقيقة. فالمقصود أنَّ الحقيقة إنْ تصورها بباطنه أو بظاهرة استغنى عن الحد القولي، وإن لم يتصورها بذلك امتنع أن يتصور حقيقتها بالحد القولي، وهذا أمر محسوس يجده الإنسان في نفسه بـانه

1- ابن تيمية، الرد على المنطقيين، ص184. 
فإن من عرف المحسوسات المتذوقة -مثلاً- كالعسل لم يفده الحد تصورها، ومن لم يذق ذلك - كمن أخبر عن السكر وهو لم يذقه- فهو لا يمكن أن يتصور حقيقته بالكلام والحد؛ بل يمثل له ويقرب إليه، ويقال له: طعمه يشبه كذا أو يشبه كذا وكذا، وهذا التشبيه والتمثيل ليس هو الحد الذي يدعونه.

وكذلك المحسوسات الباطنة مثل الغضب والفرح والحزن والغم والعلم ونهو ذلك من

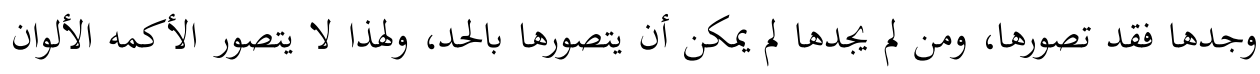
بالحد ولا العنّين الوقاع بالحد، فإذن القائل بأن الحدود هي التي تفيد تصور الحقائق قائل للباطل

المعلوم بالحس الباطن والظاهر (1). والواضح من هذا النص أن ابن تيمية يعلق معرفتنا بالعالم الخارجي على الحواس أي أنه أعلا من شأن المعرفة الحسية، ويرى أن الحواس هي وسيلة معرفتنا بالأشياء، ويرى أن الحقيقة إما تيأ

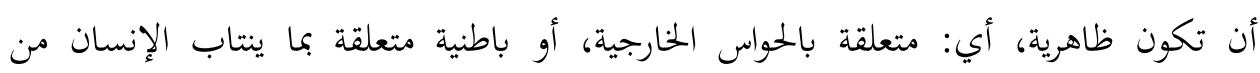
مشاعر الخوف والغضب والفرح والحزن، ويؤكد ابن تيمية أن هذه المعرفة الظاهرية والمعرفة الباطنية

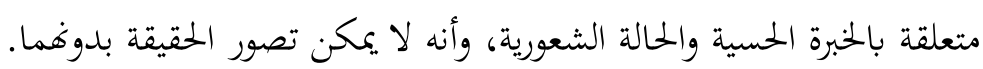

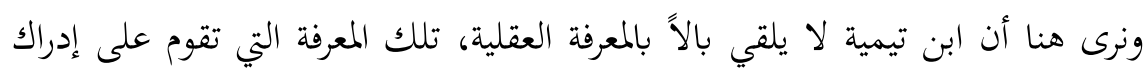

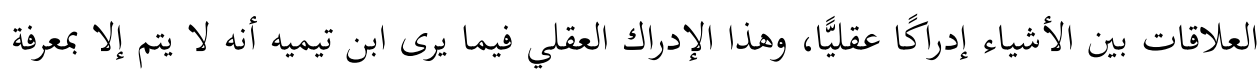

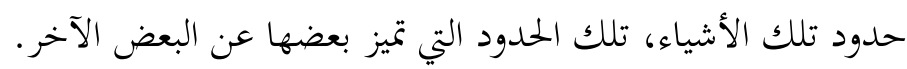
د. قول المناطقة: "أن الحدود إنما هي أقوال كلية": يرى ابن تيمية أن الحدود الكلية تدل على معنى كلي، والمعاني الكلية وجودها في الذهن

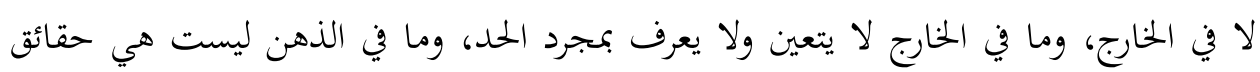

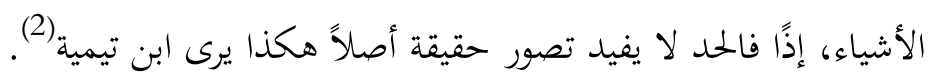

1- ابن تيمية: نقض المنطق، ص186.

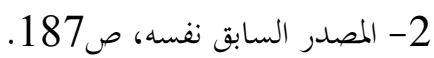


وهنا نجد ابن تيمية يعترف بوجود معان كلية في الذهن ولكنه ينكر تمامًا أن يكون لها كليات في الخارج، وإذا سرنا معه في هذا القول فكيف نفسر وجود تلك المعاني الكلية الموجودة في الذهن، والتي لا يقابلها شيئًا كليًا في الواقع الخارجي؛ ثم من أين للإنسان هذه المعاني الكلية؟ هذه هي ملامح موقف ابن تيمية من المنطق الأرسطي وهذه الملامح تدل على أن ابن تيمية لم يتوجه إلى نقد المنطق من فراغ؛ ولكنه توجه إلى هذه الانتقادات من خبرة سابقة بالمنطق، صحيح أن ابن تيمية وإذا كان قد قدم لنا نقدًا منهجيًّا للمنطق إلا أنه في كتابه نقض المنطق قد وقع في بعض التناقضات التي لا مبرر لها غير مهاجمة محاولة إدخال المنطق إلى العلوم الإسلامية تلك المحاولة التي قام بها الإمام الغزالي.

\section{ثانيا: موقف فتهاء المفرب العربي من المنطق الأرسطي:}

قد كان موقف فقهاء المغرب العربي ومعظمهم من أتباع المذهب المالكي من محتي محاولة الغزالي موقفًا سلبيَّا، حيث يذكر بعض المؤرخين أن كل العلوم عند الأندلسيين كان لها حظ كبير واعتناء عدى الفلسفة والمنطق والتنجيم، حيث كان يطلق اسم زنديق على كل من يقرأ الفلسفة أو يشتغل بالتنجيم، وقد تصل الدرجة إلى رجمه بالحجارة أو قتله قبل أن يصل أمره للسلطان تقربًا لقلوب العامة(1). ويروي لنا "الحجاج يوسف بن تُحَّة بن طلموس ت620هـ" في حديثه عن زهد العلماء بالأندلس في صناعة المنطق إذ يقول: (( فإني رأيتها مرفوضة عندهم، مطروحة لديهم، لا يحفل بها ولا يلتف إليها؛ وزيادة إلى هذا أن أهل زماننا ينفرون ويرمون العالم بها بالبدع والزندقة )(2). 1- أحمد بن مُحَّمَ المقري التلمساني: نقح الطيب من غصن الألاندلس الرطيب، تحقيق د.إحسان عباس، دار الصياد، بيروت، د ن ت، ص205.

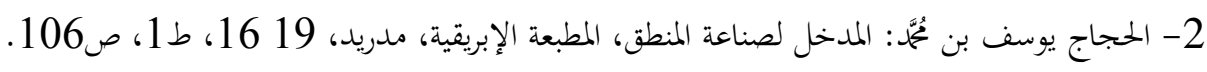


لقد بلغت معاداة الفقهاء للمنطق إلى حد أن أهل المنطق بجزيرة الأندلس كانوا يعبرون

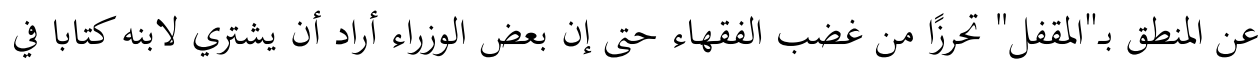
المنطق فاشتراه خفية خوفًا منهم (1). ولهذا السبب يذكر ابن طلموس أن الإمام الغزالي حينما كتب في المنطق لم يعرض أبحاثه

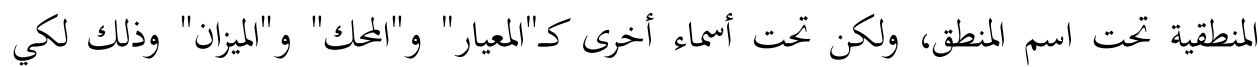

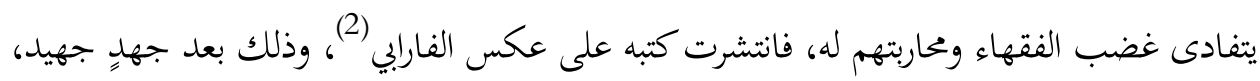
فلقد قوبلت كتب الغزالي في أواخر دولة المرابطين بالإعراض والتبرم، حيث يقول "عبد الواحد المراكشي ت647هـ": (( ولما دخلت كتب الغزالي -رحمه الله- بالمغرب أمر أمير المسلمين علي ابن يوسف بإحراقها وهدد بالوعيد الشديد من سفك الدماء، واستئصال المال إلى من وجد عنده شيء

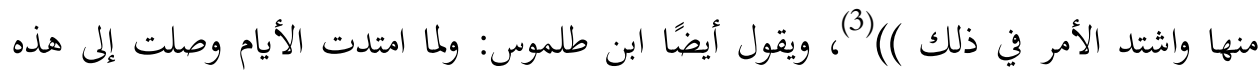

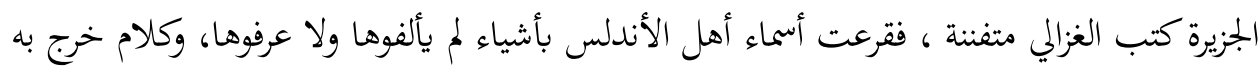

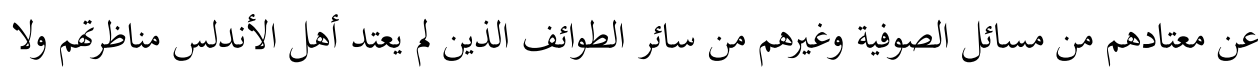

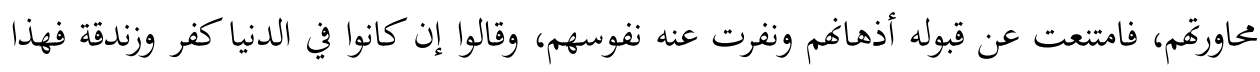

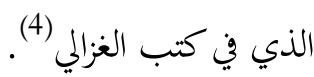
ولكن هذا التصور يبدو أنه ناشئ بالدرجة الأولى عما آل إليه أمر الغزالي من النزعة

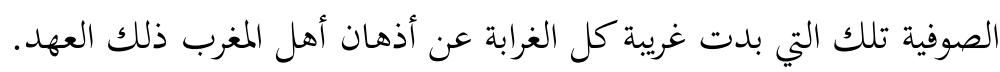
إلا أن الأقدار قد شاءت أن يدرس على الغزالي اثنان من المغاربة الأندلسيين أصبحا

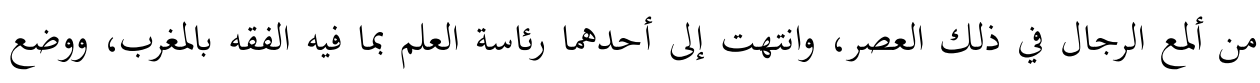

$$
\begin{aligned}
& \text { 1- ابن حيان الأندلسي: تفسير البحر المحيط، ط5، ص19 } 3 .
\end{aligned}
$$

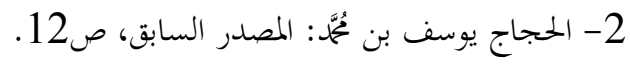

3- عبد الواحد بن علي المراكشي، المعجب في تلخيص أخبار العرب، تحقيق نُمَّمَ سعيد العريان، لجنة إحياء

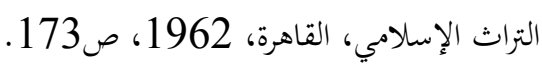

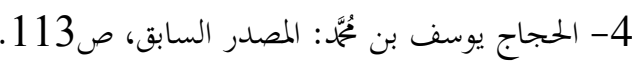


الثاني مذهبًا إصلاحيَّا سياسيَّا كان أساسًا لقيام دولة من أعظم ما عرف المغرب؛ بل بلاد الإسلام، وقد تأثر الرجلان بتفكير الغزالي وعلمه، وعمل كل واحد منهم على نشر ذلك

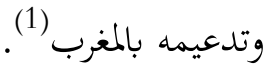

أما أول الرجلين فهو "أبو بكر بن عبد الله بن العربي 468-543هه"، فقد التقى بالغزالي في رحلته العلمية إلى المشرق العربي، وتتلمذ عليه ولازمه مدة ودرس عليه بعض كتاباته، وقد ذكر هو نفسه ذلك إذ يقول: (( قرأت عليه جملة من بعض كتبه، وسمعت كتابه الذي سماه بالإحياء لعلوم الدين ()(2).

ومن المؤكد أن يكون من بين تلك الكتب بعض كتب الغزالي المنطقية، وذلك أننا نجده

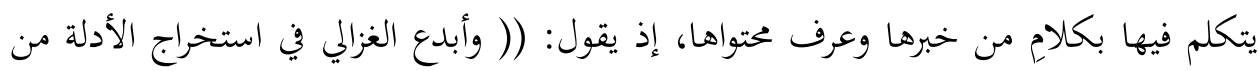
القرآن على رسم الترتيب في الوزن الذي شروطه على قوانين خمسة بديعه في كتاب سماه "القسطاس المستقيم" ما شاء، وأخذ في "معيار العلم" عليهم طريق المنطق، نرتبه بالأمثلة

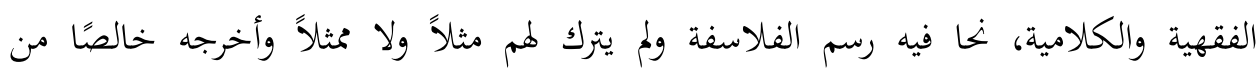

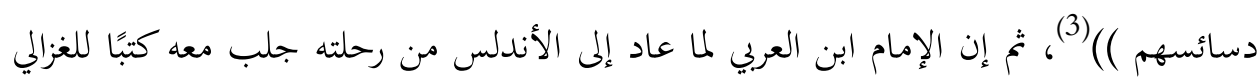
وكان من بينها كتبه المنطقية كــ"محك النظر" و "معيار العلم".

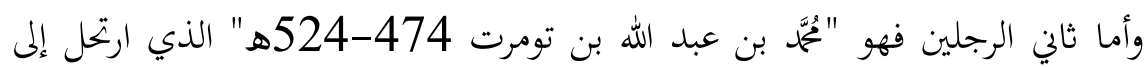
المشرق العربي لطلب العلم ودرس بمكة وبغداد ودمشق والإسكندرية(4)، وقد قابل الغزالي ويبدو أنه أخذ عنه المذهب الأشعري.

$$
\begin{aligned}
& \text { 1- الحجاج يوسف بن مُحَّم: المصدر السابق، ص113 } \\
& \text { 2- المصدر السابق نفسه، ص138. }
\end{aligned}
$$

3- أبوبكر بن عبد الله بن العربي، العواصم من القواصم، تحقيق د.عمار طالب، الشركة التونسية للنشر

$$
\text { 4- المصدر السابق نفسه، الجزائر،19 74، ط2، ص107 ص106. }
$$


وقد أشار ابن خلدون إلى مكانة ابن تومرت فقال: (( كان إمام من أئمة العلم ذا ملكة راسخة وقوة على النظر والجدل؛ بحيث يضاهي كبار الشخصيات العلمية البارزة والتي

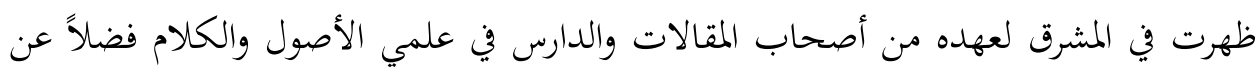
تضلعه في الفقه والحديث ())

وبغض النظر عن لقاء ابن تومرت بالغزالي وأخذه عنه كما أثبته بعض المؤرخين، ونفاه بعض المستشرقين أو عدم لقائه به فإنه قد تأثر بفكر الغزالي وتشبع بأفكاره الإصلاحية، فبالإضافة إلى تأثره بفكرة رجوعه إلى الأصول الإسلامية والتلطيف من محدودية الأحكام الفقهية

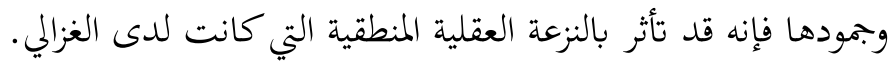

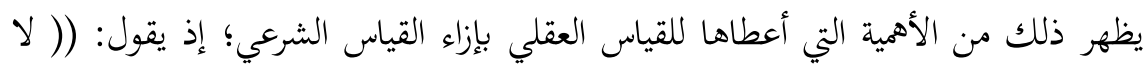
فرق بين القياس العقلي والقياس الشرعي في الاطراد إذا حقق معناه ؛ فإن القياس العقلي هو المساواة فيما يجب ويستحيل، والقياس الشرعي هو المساواة في الوجوب والتحليل والتحريم )(2). كما يظهر أيضًا في نقده لبعض الطرق الاستدلالية التي كان يستعملها المتكلمون

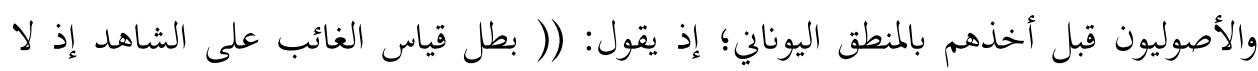

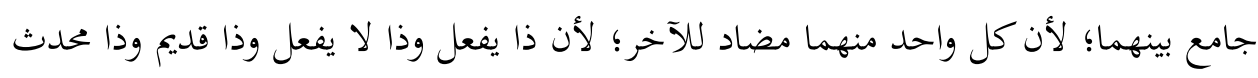
وذا مفتقر وذا غني، فإذا قيس أحدها على الآخر بطلت حقيقتهما جميعًا؛ لأن القياس إنما يضع

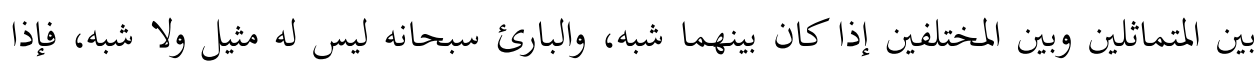
ثبت هذا وصح بطل به التشبيه، وبطل به قياس الغائب على الشاهد )( (3).

1- ابن خلدون، تاريخ ابن خلدون، دار الكتب العلمية، بيروت-لبنان،19 99، ط1 19، ص266.

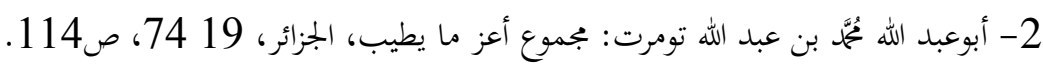
3- المصدر السابق نفسه، ص168. 
وقد استجمع ابن تومرت في سبيل الاستدلال على فساد قياس الغائب على الشاهد

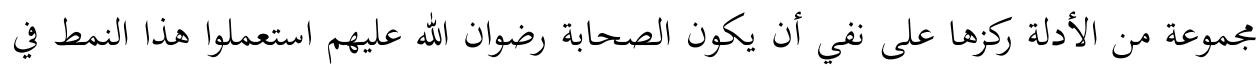

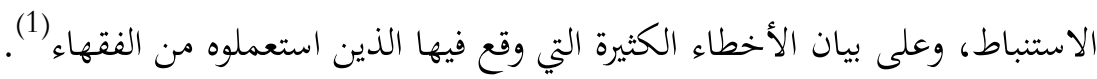
ثم إن ابن تومرت عمل على إفساد آراء الغزالي وندب الناس بئاس إلى قراءة كتبه ودراستها

والعمل كها (2)

يتضح لنا مما سبق أن ابن تومرت ومن قبله ابن العربي لم يقم كل منهما مباشرة بإدخال المنطق في الدراسات الفقهية؛ بل كان ابن العربي يرى وجوب التحري في ذلك؛ لأنه إذا ما أسند إلى غير كفء باء الضرر الكبير؛ وكان يوصي بذلك تلاميذه؛ إذ يقول: (( الذي أراه لكم على إلى

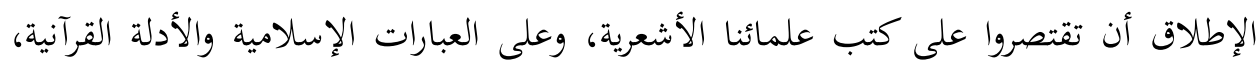

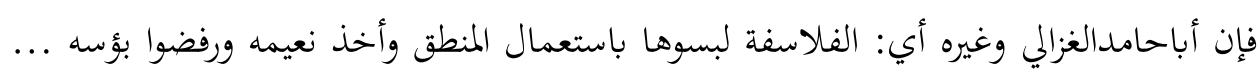

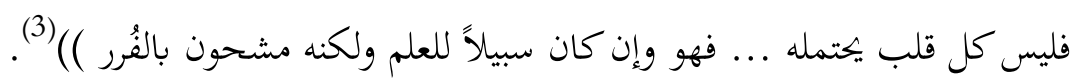
كما أن ابن تومرت كان منصرفًا عن ذلك إلى وضع الأسس الإصلاحية العامة لقيام دولة الموحدين، ولكنهما -ابن العربي وابن تومرت- قد مهدا الطريق إلى ذلك بما قد أفشيا

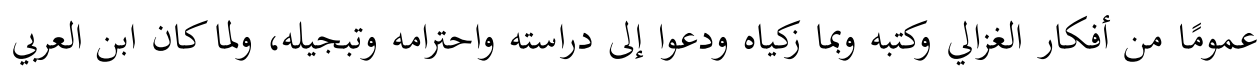

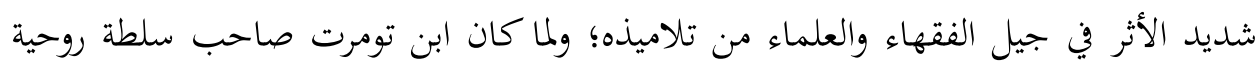

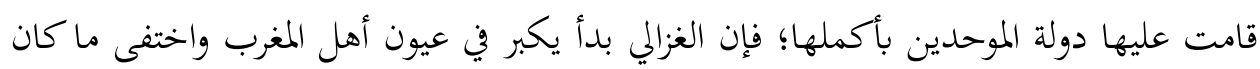

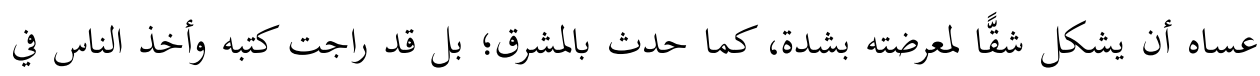

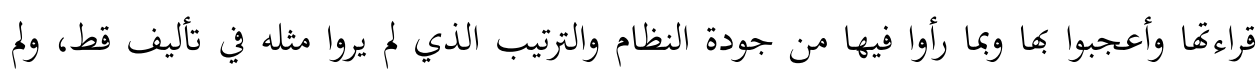
يبق في هذه الجهات من لم يغلب عليه حب كتب الغزالي.

1- الحجاج بن يوسف نُمَّم: المدخل لنصاعة المنطق، ط1، ص12.

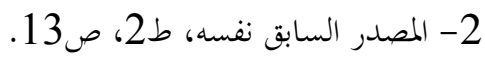

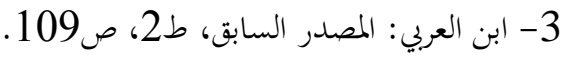


ومن بين تلك الكتب كتبه في المنطق، ويظهر أن كتب المنطق لم تصل إلى المغرب إلا

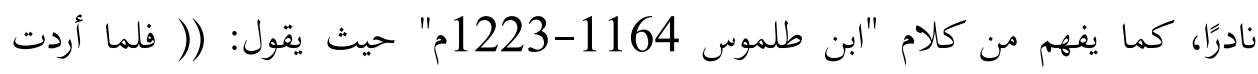

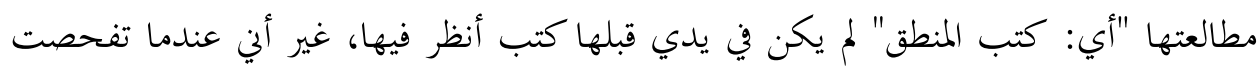

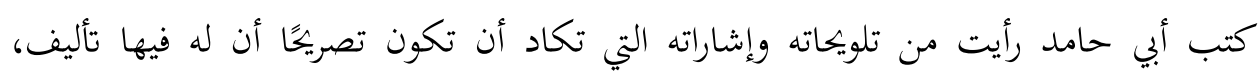

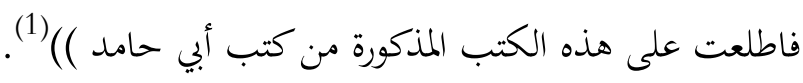
بعد هذه التهيئة النفسية والذهنية لتقبل المنطق وإدخاله في الدراسات الفقهية التي استغرقت

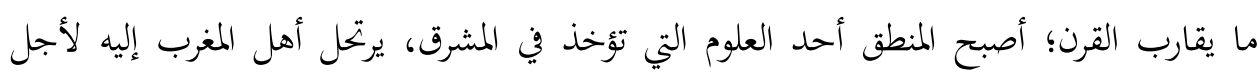

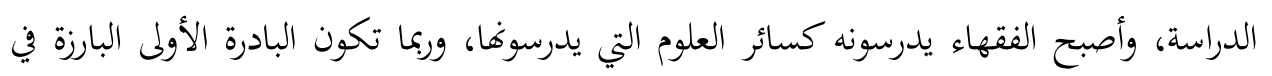

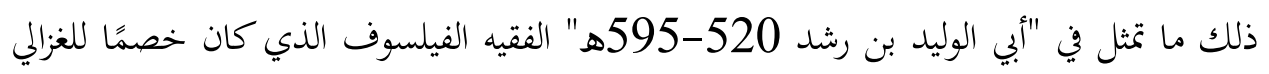

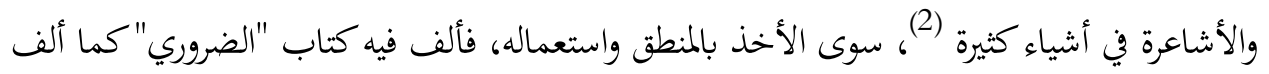
في الفقه "بداية المجتهد وهماية المقتصد". ودخل المنطق بعد ذلك ضمن تقاليد الرواية بالانتقال من جيل إلى جيل بطريق التدريس بجامعتي المغرب المعمورتين على الأخص: الزيتونة بتونس والقرويين بفاس (3).

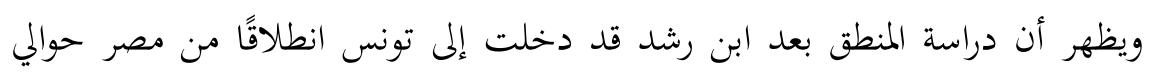

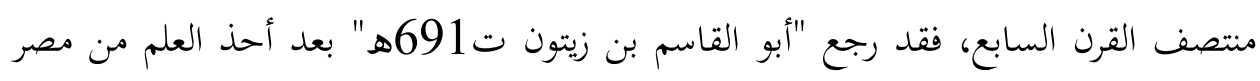

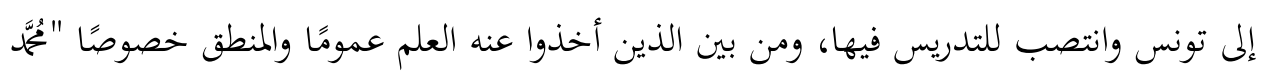
بن يمي بن عمر بن الحباب ت741هه" الذي أصبح إمامًا بارعًا في الفقه والأصول والمنطق.

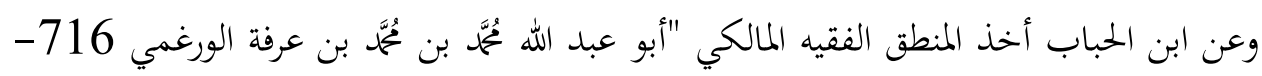

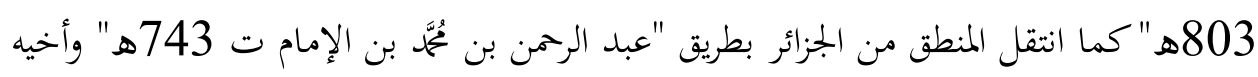

$$
\text { 1- 2- ابن العربي، العواصم من القواسم، ص140. }
$$

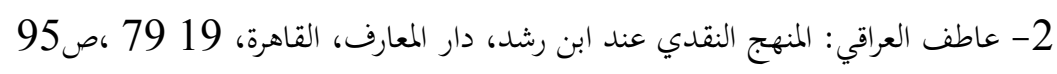

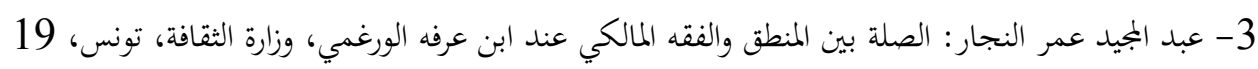

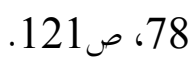


عبس وعن طريق "أبي علي ناصر الدين الشدالي" وتوالى في تلاميذهم (1) حتى وصل الفقيه العالم "عبد الرحمن بن عُمَّم الأخضري 918-983هـ" فألف فيه منظومته الشهيرة التي سماها

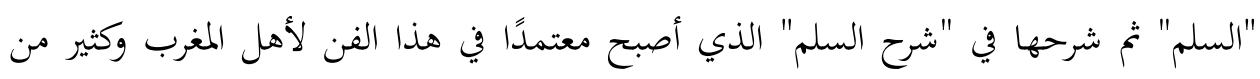
أهل المشرق (2) - (2)

1- ابن خلدون: المقدمة، المؤسسة العربية للدراسات والنشر، بيروت، 1984، ص431.

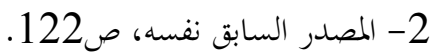


الخاتمة

1. لاقت محاولة الغزالي لربط المنطق بالفقه ردود أفعال مختلفة سواء أكانت في المشرق

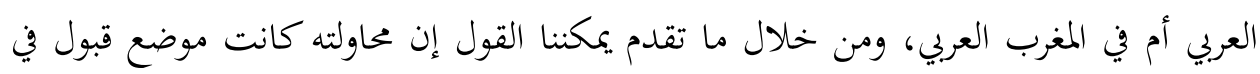
المغرب أكثر منها في المشرق.

2. منذ موقف الإمام الشافعي من المنطق، وحتى فتاوى ابن الصلاح بتحريم المنطق،

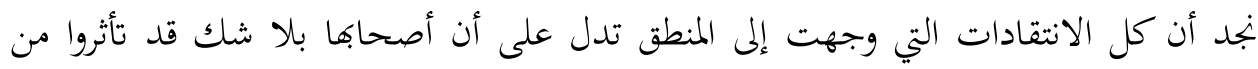
قريب أو من بعيد بالمنطق الأرسطي، كما تميزت انتقاداقم بالطابع السطحي أكثر منها محاولة جادة لبيان قصور المنطق. 3. قام نقد ابن تيمية على أسس واعية وإدراك لكثيرٍ من المعاني المنطقية التي تناولها، لذا جاءت انتقاداته منصبة على روح المنطق ذاتا.

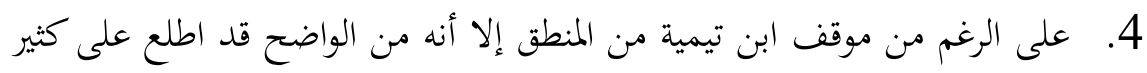
من كتب المنطق، وبخاصة "القسطاس المستقيم" للإمام أبي حامد الغزالي. 5. وقع ابن تيمية في بعض التناقضات وبخاصة في حديثه عن بطلان قول المناطقة بالحد الكلي كمعين للوصول إلى الحقيقة، ومن هذه التناقضات اعترافه بوجود المعاني الكلية في الذهن في الوقت الذي أنكر فيه عدم وجود مدلولات لها في الواقع الخارجي.

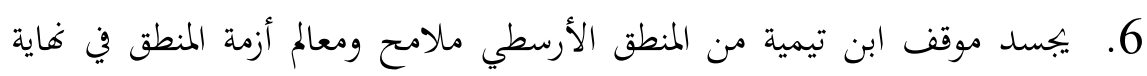
القرن السابع الهجري، وبداية القرن الثامن الهجري.

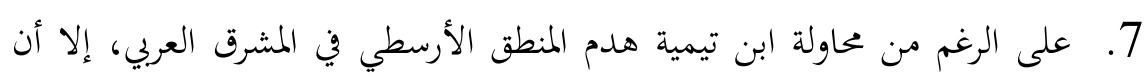

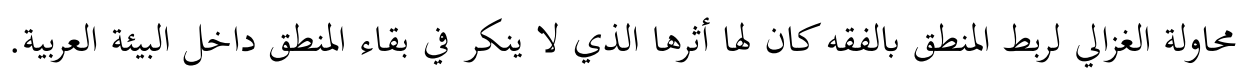




\section{المصادر والمراجع}

1- ابن السبكي، طبقات الشافعية، المطبعة الحسينية، ج: 5، ط: 1 القاهرة، د ن ت. ت. 2- ابن الصلاح: فتاوى ابن الصلاح في التفسير والحديث والأصول والفقه، حققه وعلق عليه:

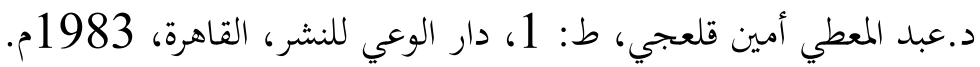

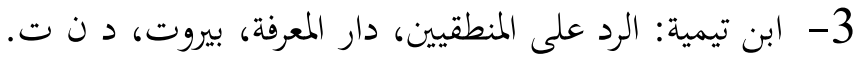

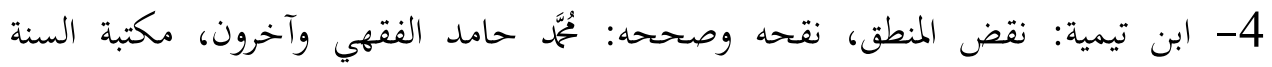

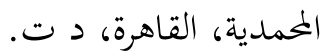
5- ابن حيان الأندلسي: تفسير البحر المحيط، دار احياء التراث العربي، بيروت، د ت، ط: 5.

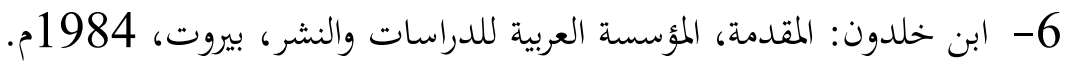

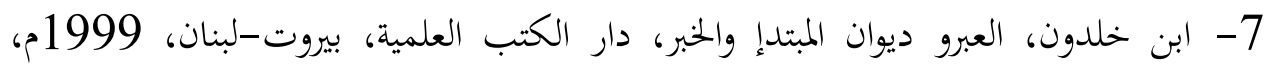

$$
\text { 8- ج: 1. 1. } 1 \text { جن منظور: لسان العرب، دار المعارف، القاهرة، د ن ت، ط: } 5 .
$$
9- أبوبكر بن عبد الله بن العربي، العواصم من القواصم، تحقيق د. عمار طالب، الشركة

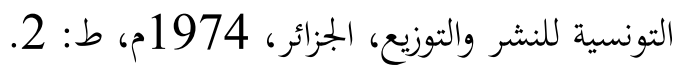

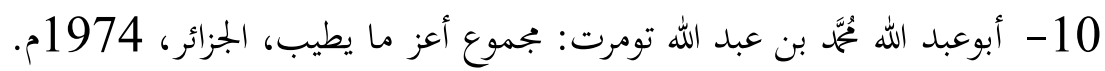
11 - أحمد بن عُمَّل المقرى التلمساني: نفح الطيب من غصن الاندلس الرطيب، تحقيق إحسان عباس، دار الصياد، بيروت، د ن ت. تهن. 12- الحجاج يوسف بن مُحَّم: المدخل لصناعة المنطق، المطبعة الابريقية، مدريد، 1916م، b: $1:$ 13 - جلال الدين السيوطي: صون المنطق والكلام عن فن المنطق والكلام، علق عليه: علي سامي النشار، مطبعة السعادة، القاهرة، 1946م.

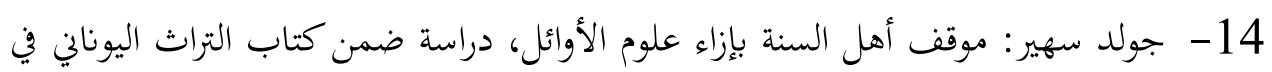

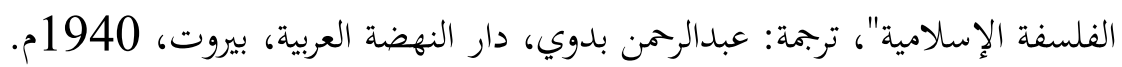


15 - حسن عبد الحميد: المنهج في علم أصول الفقه، ضمن كتاب في فلسفة العلوم ومناهج

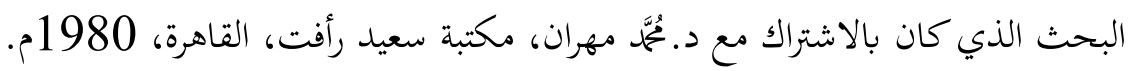
16 - طاش كبرى زاده: مفتاح السعادة ومصباح السيادة، ط: 1، م: 3، دار الكتاب العلمي، بيروت، د ن ن ت ت ن

17 - عاطف العراقي: المنهج النقدي عند ابن رشد، دار المعارف، القاهرة، 1979م. 18 - عبد المجيد عمر النجار: الصلة بين المنطق والفقه المالكي عند ابن عرفه الورغمي، وزارة

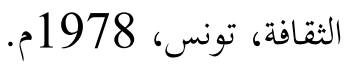
19- عبد الواحد بن علي المراكشي، المعجب في تلخيص أخبار العرب، تحقيق تُحَّمَ سعيد

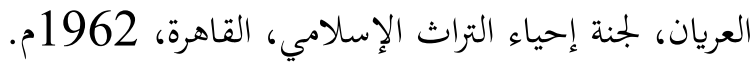
20- تُحَّمَ عابد الجبري: تكوين العقل العربي، مركز دراسات الوحدة العربية، بيروت، ط: 5، 1991 21- تُحَّة عبد الستار نصار، المدرسة السفلية وموقف رجاها من المنطق وعلم الكلام، دار الأنصار للطباعة والنشر والتوزيع، 1979م. 